\title{
KUALITAS HIDUP PASIEN GAGAL GINJAL KRONIS YANG IMENJALANI HEIMODIALISIS DI RSUD Dr. DORIS SYLVANUS PALANGKA RAYA
}

\author{
Quality of Life of Chronic Kidney Disease Patients on Hemodialysis at Dr. Doris Sylvanus \\ Hospital Palangka Raya
}

\author{
*Dewi Sari Mulia, Evi Mulyani, Guntur Satrio Pratomo \& Nurul Chusna \\ Department of Pharmacy, Faculty of Health Science, Universitas Muhammadiyah Palangkaraya, RTA. Milono St. Km. I.5 Palangka Raya, \\ Indonesia \\ *e-mail : dewisarimulia@gmail.com
}

\begin{abstract}
ABSTRAK
Penyakit ginjal mencakup berbagai penyakit dan gangguan yang mempengaruhi fungsi ginjal. Jika tidak segera diobati maka akan terjadi gagal ginjal. Pasien Gagal Ginjal Kronis (GGK) memerlukan hemodialisis akibat mengalami gangguan fungsi endokrin, metabolik, cairan elektrolit serta asam basa. Hemodialisis merupakan tindakan pengganti fungsi ginjal untuk mengeluarkan sisa metabolisme. Tindakan hemodialisis tersebut dapat berdampak terhadap kualitas hidup pasien. Tujuan penelitian ini adalah untuk mengetahui kualitas hidup pasien GGK yang menjalani terapi hemodialisis di RSUD dr. Doris Sylvanus Palangka Raya. Penelitian ini menggunakan metode kuantitatif univariat dengan pendekatan deskriptif. Data dikumpulkan dengan menggunakan kuesioner yang diadopsi dari Word Health Organization Quality of Life (WHOQoL)-BREF yang berisi 26 item pertanyaan yang meliputi empat dimensi yaitu fisik, psikologis, lingkungan dan sosial. Sampel yang digunakan dalam penelitian ini sebanyak 30 orang. Hasil penelitian menunjukkan bahwa kualitas hidup pasien untuk domain fisik dan psikologis termasuk dalam kategori sedang, sedangkan domain lingkungan dan sosial termasuk kategori baik.
\end{abstract}

Kata kunci: Kualitas hidup, gagal ginjal kronis, hemodialisis

\section{ABSTRACT}

Kidney disease includes various diseases and disorders affecting the kidney function. If not treated immediately then there will be kidney failure. Patients with Chronic Kidney Disease (CKD) require hemodialysis due to impaired endocrine, metabolic, electrolyte and acid-base functions. Hemodialysis is a substitute for kidney function to remove the rest of the metabolism. These hemodialysis actions can affect the quality of life of patients. The purpose of this study was to determine the quality of life of CKG patients undergoing hemodialysis therapy in dr. Doris Sylvanus Hospital Palangka Raya. This research uses univariate quantitative method with descriptive approach. Data were collected using a questionnaire adopted from the World Health Organization Quality of Life (WHOQoL)-BREF containing 26 items of questions covering four dimensions: physical, psychological, environmental and social. The sample used in this study as many as 30 people. Based on the assessment of quality of life in this study showed that physical and psychological dimensions including in moderate quality of life, and environmental and social dimensions including in good quality of life.

Keywords: Quality of live, chronic kidney disease, hemodialysis

\section{PENDAHULUAN}

Salah satu penanganan yang dilakukan untuk penderita CKD adalah hemodialisa. Hemodialisis (HD) merupakan tindakan untuk menggantikan sebagian dari fungsi ginjal yang dilakukan secara rutin pada pasien CKD di renal unit fasilitas kesehatan seperti Rumah Sakit. Di Indonesia berdasarkan Report Of Indonesian Renal Registry 2014 terdapat 358 renal unit dengan bentuk instalasi di rumah sakit 334 dan status kepemilikan pemerintah. Peningkatan jumlah renal unit menandakan meningkatnya kebutuhan pasien CKD dalam menjalani HD. Lebih dari 380.000 penderita GGK menjalani hemodialisis reguler (USRDS, 20II). Pada tahun 20II di Indonesia terdapat I5353 pasien yang baru menjalani HD dan pada tahun 2012 terjadi peningkatan pasien yang menjalani HD sebanyak 4268 orang (IRR, 20I3). Berdasarkan data RSUD Doris Sylvanus, terjadi peningkatan jumlah pasien CKD yang menjalani HD di Palangka Raya yaitu dari 8.518 pasien pada tahun 2014 menjadi 9.743 pada tahun 2015 .

Pada pasien CKD yang menjalani hemodialisis sering dilaporkan mengalami penurunan kualitas hidup, menurut Rahman et al (20I3) pada pasien CKD terdapat penurunan kualitas hidup pasien baik dari segi fisik, mental, sosial dan lingkungan. Kualitas hidup pasien CKD yang menjalani HD menjadi hal yang menarik perhatian paramedis, karena hakikatnya tujuan HD adalah untuk mempertahankan kualitas hidup pasien. Lacson (2010) menjelaskan bahwa 
pada pasien CKD terjadi terjadi penurunan kualitas hidup yang meliputi kesejahteraan fisik, mental dan sosial. World Health Organization Quality of Life mengemukakan kualitas hidup adalah persepsi individu dalam kemampuan, keterbatasan, gejala serta sifat psikososial hidupnya dalam konteks budaya dan sistem nilai untuk menjalankan peran dan fungsinya (WHO, 2016). Penelitian yang dilakukan Sathvik et al (2008) di salah satu unit pelayanan kesehatan di India dengan menggunakan WHOQOL-Breef sebagai instrumen menunjukan bahwa kualitas hidup individu sehat atau transplantasi ginjal jauh lebih baik dibandingkan dengan pasien yang menjalani HD.

Kualitas hidup dijadikan sebagai aspek untuk menggambarkan kondisi kesehatan dapat dinilai berdasarkan kesehatan fisik, psikologis, hubungan sosial dan lingkungan. Dalam kondisi sehat kualitas hidup manusia akan selalu terjaga dimana ke empat aspek tersebut dapat dijalankan dengan baik. Hal ini akan berbeda jika manusia dalam kondisi sakit, dimana faktor yang paling terlihat dalam penurunan kualitas hidupnya adalah kondisi fisik. Terlebih pada penderita penyakit kronis, salah satunya adalah CKD. Pada pasien CKD terjadi penurunan kondisi fisik seperti berat badan dan kemampuan mobilitasnya. Pasien CKD harus menjalani hemodialisa dengan penjadwalan teratur dari I (satu) sampai 3 (tiga) kali dalam seminggu, hal ini dapat mempengaruhi hubungan sosial dan psikologisnya secara tidak langsung. Terkait dengan beberapa permasalahan tersebut, peran farmasis sebagai tenaga kesehatan sangat dibutuhkan untuk menjaga dan meningkatkan kualitas hidup pasien CKD.

\section{METODOLOGI}

\section{Alat dan Bahan}

Alat yang digunakan dalam penelitian ini dibuat dalam bentuk kuesioner yang diadopsi dari Word Health Organization Quality of Life (WHOQoL)-BREF yang berisi 26 item pertanyaan yang meliputi empat dimensi yaitu fisik, psikologis, lingkungan dan sosial. Alat ukur ini telah diadaptasi ke berbagai bahasa, termasuk bahasa Indonesia oleh Dr. Riza Sarasvita dan Dr. Satya Joewana untuk penelitian pada drug user. Selain itu, alat ukur adaptasi ini juga digunakan oleh Wardhani (2006) untuk meneliti kualitas hidup pada dewasa muda lajang. Uji validitas yang dilakukan oleh Wardhani (2006) adalah uji validitas item dengan cara menghitung korelasi skor masing-masing item dengan skor dari masing-masing dimensi WHOQOLBREF. Hasil yang didapat adalah ada hubungan yang signifikan antara skor item dengan skor dimensi ( $r=$ 0,409-0,805) sehingga dapat dinyatakan bahwa alat ukur
WHOQOL-BREF adalah alat ukur yang valid dalam mengukur kualitas hidup (Sekarwiri, 2008).

\section{Metode Penelitian}

Penelitian ini merupakan merupakan penelitian deskriptif dengan pendekatan Single Cross Sectional.

\section{Analisis Data}

Analisa data yang digunakan dalam penelitian ini adalah analisis univariat yang bertujuan untuk menjelaskan atau mendeskripsikan karakteristik setiap variabel penelitian (Notoadmodjo, 2010). Analisis secara deskriptif ini nantinya menghasilkan distribusi dan persentase dari setiap variabel dan disajikan dalam bentuk narasi, tabel dan diagram. Rumus yang dipakai untuk menghitung adalah rumus baku yang sudah ditetapkan WHO, sebagai berikut:

$$
\text { TRANSFORMED SCORE }=(\operatorname{SCORE}-4) \mathrm{X}\left(\frac{100}{16}\right)
$$

Hasil dipresentasikan dengan cara pemberian skor dan diinterpretasikan dengan menggunakan kriteria sebagai berikut:

0-20 = kualitas hidup sangat buruk

$21-40=$ kualitas hidup buruk

$4 \mid-60=$ kualitas hidup sedang

$6 \mathrm{I}-80=$ kualitas hidup baik

$81-100=$ kualitas hidup sangat baik

\section{HASIL DAN PEMBAHASAN}

Tabel I. Hasil Penilaian Kualitas Hidup untuk Setiap Domain

\begin{tabular}{lcc}
\hline Domain & Transformed Score (0-1 00) & $\begin{array}{c}\text { Kualitas } \\
\text { Hidup }\end{array}$ \\
\hline Fisik & 52 & Sedang \\
Psikologis & 56 & Sedang \\
Sosial & 66 & Baik \\
Lingkungan & 63 & Baik \\
\hline
\end{tabular}

Hasil penelitian menunjukkan bahwa domain fisik dan psikologis pasien termasuk dalam kategori kualitas hidup sedang, sedangkan untuk domain sosial dan lingkungan termasuk dalam kategori kualitas hidup baik. Menurut Mc. Cartney dan Larson dalam Yuwono (2000) menyatakan bahwa ada hubungan yang berbanding terbalik antara kualitas hidup pasien dengan usia, semakin tua usia seseorang, maka kualitas hidupnya juga akan menurun. Kurtus (2005) menyebutkan bahwa kualitas hidup terdiri dari tiga komponen, yaitu kesehatan, kepemilikan dan harapan, sehingga hal ini tentu juga terkait dengan faktor umur, tingkat pendidikan, dan status pekerjaan. 
Kondisi depresi yang dialami oleh pasien juga akan sangat berpengaruh pada penilaian kualitas hidup (Bohlke et al., 2008). Pasien yang mengalami depresi cenderung menunjukkan sikap menentang terhadap program pengobatan, sehingga mereka tidak menjalani terapi HD reguler sesuai jadwal, dan hal ini akan berpengaruh terhadap adekuasi HD, yang akan berdampak pada kesehatan fisik mereka. Menurut Rasmun (2004), ada beberapa faktor yang memengaruhi respons terhadap stressor, yaitu bagaimana individu mempersepsikan stressor, bagaimana intensitasnya terhadap stimulus, jumlah stressor yang harus dihadapi dalam waktu yang sama, lamanya pemaparan stressor, pengalaman masa lalu, serta tingkat perkembangan.

Pasien yang menjalani hemodialisis memiliki kondisi yang sama ketika mereka didiagnosis gagal ginjal kronis. Lamanya pengobatan hemodialisis memainkan peran penting bagi pasien gagal ginjal kronis. Pasien yang melakukan cuci darah dua kali/minggu memiliki kualitas hidup yang baik dibandingkan pasien yang melakukan dialisis tiga kali/minggu (Bohlke et al., 2008). Hemodialisa dua kali seminggu membantu pasien meningkatkan kualitas hidup mereka, karena kurangnya komplikasi, tingkat uremia menurun dari waktu ke waktu, dan kurangnya diuresis residual (Guerrero et al., 2012).

\section{KESIMPULAN}

Hasil penelitian menunjukkan bahwa kualitas hidup pasien untuk domain fisik dan psikologis termasuk dalam kategori kualitas hidup sedang, sedangkan domain lingkungan dan sosial termasuk kategori kualitas hidup baik.

\section{DAFTAR PUSTAKA}

Bohlke, M., Nunes, D. L., Marini, S. S., Kitamura, C., Andrade, M., \& Von-Gysel, M. P. O. 2008. Predictors of quality of life among patients on dialysis in Southern Brazil. Sao Paulo Medical Journal, I26, 252-256.

Indonesian Renal Registry. 2013. 6th Report Of Indonesian Renal Registry: Pasien baru dan pasien aktif di Indonesia. http://www.indonesianrenalregistry.org (Diakses 30 Oktober 2016).

Indonesian Renal Registry. 2014. 7th Report Of Indonesian Renal Registry: Jumlah Unit Renal di Indonesia. http://www.indonesianrenalregistry.org (Diakses 30 Oktober 2016).
Kurtus. 2005. University of Toronto Quality of Life Model. http://www.school-forchampions.com (Diakses 29 Juli 2018).

Lacson, E.J.R., Xu, J., Lin, SF., Dean, SG., Lazarus, JM and Hakim, RM. 2010. A comparasion of SF436 and SF4I2 composite score and subsequent hospitalization and mortality risks and longterm dialysis patient. Clinical Sciences. USA.

Notoatmodjo. 2010. Metodologi Penelitian Kesehatan. PT. Rineka Cipta, Jakarta.

Nurchayati, S. 2010. "Analisa Faktor-Faktor yang Berhubungan dengan Kualitas Hidup Pasien Penyakit Ginjal Kronik yang Menjalani Hemodialisis di Rumah Sakit Islam Fatmawati Cilacap dan Rumah Sakit Umum Daerah Banyumas". Tesis. Universitas Indonesia.

Guerrero, G. V., Alvarado, O. S., \& Espina, M. C. 2012. Quality of life in people with chronic hemodialysis: association with sociodemographic, medicalclinical and laboratory variables. Revista Latino-Americana de Enfermagem, 20: 838-846.

Rahman, ARA., Rudiansyah, $M$ and Triawanti. 2013. "Hubungan antara adekuasi hemodialisis dan kualitas hidup pasien di RSUD Ulin Banjarmasin”. Berkala Kedoketeran, 9(2): I5I-160.

Rasmun. 2004. Stres, Koping dan Adaptasi: Teori dan Pohon Masalah Keperawatan. Edisi I. Jakarta: Sagung Seto.

Sathvik, B. S., Parthasarathi,G.M., Narahari., G and Gurudev, K. C. 2008. An assessment of the quality of life in hemodialysis patients using the WHOQOL-BREF questionnaire. Indian J Nephrol, I8(4): $|4|-\mid 49$.

Sekarwiri, E. 2008. Hubungan antara kualitas hidup dengan sense of community pada warga DKI jakarta yang tinggal di daerah rawan banjir. http://www.lontar.ui.ac.id (Diakses 29 Oktober 2016).

USRDS. 2013. Incidence, prevalence, patient characteristik and treatmen modalities. Vol. 2. USA. http://usrds.go.org (Diakses 25 Oktober 2016).

Yuwono, A. 2000. Kualitas Hidup Pasien. Jakarta: FKUI, hal I-5.

World Health Organization. 2016. Management of substance abuse: WHO Quality of Life-BREF (WHOQOL-BREF). http://www/who.int (Diakses OI November 2016). 